\title{
Research on the School-Enterprise Cooperation in Running Schools in Higher Vocational Education
}

\author{
Lin Wang \\ Shandong Yingcai University,Ji'nan, 250022, China
}

\begin{abstract}
Keywords: Higher vocational education. School-enterprise cooperation. High-level. School-running pattern. Problem analysis
\end{abstract}

\begin{abstract}
School-enterprise cooperation occupies an increasingly important position in development of higher vocational education. From the perspective of the basic features, the most significant of the basic characteristics of higher vocational education is High-level that fully embodied by school-enterprise cooperation. This article analyzes and states status quo of school-enterprise cooperation in higher vocational colleges and puts forwards related elaboration strategy, hoping to provide some references for sustainable development of school-enterprise cooperation in running schools in Chinese higher vocational education.
\end{abstract}

\section{Introduction}

Mission of higher vocational education is for society to develop advanced technology applications personnel and the requirement is that the students can directly work in important technical jobs with skilled performance in enterprises or units when they graduated. To achieve that goal, higher vocational colleges shall allow students to fully experience enterprise operating mode and to understand technical requirements of the enterprise by sufficient practice. Therefore, school-enterprise cooperation in running schools is the best way for implementing this strategy and the only way to make teaching quality and teaching efficiency of higher vocational colleges can be adequately protected. With the rapid development of China's economy, the traditional economic system is also gradually transformed to knowledge economy. By this time, enterprises also put forward higher requirements for technical applications personnel worked in basic job. So the development trend of higher vocational colleges will be concerned by enterprises inevitably. Therefore, school-enterprise cooperation in running schools has multiple purposes that not only ensure sustainable development of higher vocational colleges, but also better implement personnel training strategy for enterprises.

\section{Present situation of School-Enterprise Cooperation in Running Schools in Higher Vocational Education in China}

For now, most Chinese higher vocational colleges prefer to discuss decision-making and issues with relevant administrative departments of education, while neglecting opinions from enterprises. Current status quo of running schools for higher vocational colleges is still in the model of focusing on theory than practice and teaching than business, which makes school-enterprise cooperative education in running school programs in lower level. Therefore, there is a considerable gap to be resolved between higher vocational colleges and enterprises as well as between teaching objectives of higher vocational colleges and actual demands of the enterprises. Classroom teaching in higher vocational colleges never talks about actual production status of enterprises with little practical teaching activities, which leads to non-uniformity between teaching process and production situation of enterprises. Here are the details:

There is no effective combination of periodicity of business market and long-term of higher vocational college talent cultivation.

For the higher vocational colleges formed school-enterprise cooperation in running school, the teaching content of are almost restricted by demand made by enterprises and they build practice base and establish production professional guidance committee in enterprises. Meanwhile, they hire 
industry experts as member of committee and they sign professional employment internship agreements with enterprises as well as provide professional training for enterprises on campus. However, this teaching program is entirely developed by development requirements of the enterprise, overlooking actual teaching situation and teaching needs of higher vocational colleges. Therefore, there is no effective combination of periodicity of business market and long-term of higher vocational college talent cultivation in current status of school-enterprise cooperation.

There is no good mechanism in current school-enterprise cooperation in running schools.

Current school-enterprise cooperation in running schools only refers to cooperation with higher vocational college and enterprises as well as teaching in higher vocational college and production practices of enterprises instead of deeper level of thinking. This activity is also cooperation between science and technology and economy. Due to lack of financial support as well as related government policies, such cooperation is only a short-term behavior. Furthermore, higher vocational college is interested in profit. Therefore, there is no good mechanism in current school-enterprise cooperation.

\section{Constraints for sustainable development of school-enterprise cooperation in running schools}

\section{Policy constraints of school-enterprise cooperation in running schools}

From higher vocational colleges, the various policies currently being implemented are not conducive to mobilization of teachers to in-depth understand enterprises as well as serve for enterprises. For instance, the school size, teachers and the number of published papers can measure the status of school. While for enterprises, the current market is very competitive, which makes enterprises improve technological level and introduce high technology to ensure its competitiveness. Therefore, enterprises also bear higher risk. National government do not grant strong support for enterprises in personnel, funding and other relevant policies, which makes enterprises would not dare put limited funds into school-enterprise cooperation for avoiding higher risk. Under the influence of economic factors, school-enterprise cooperation in running school can be achieved through combination of production enterprises, local government, social resources, and higher vocational colleges. Of which, the role of government is critical in this relationship. That is to say, the teaching objectives of higher vocational education cannot be achieved without government guarantee of relevant policies and regulations, relationship coordination, financial support as well as quality identified instructions. China has gradually implemented a number of laws and regulations regarding vocational education and also given specific provisions for school-enterprise cooperation, but it only has poor implementation and weak driving force. The reason is because many local governments do not really understand this relationship and have no action, which will greatly inhibit sustainable development of school-enterprise cooperation.

\section{Institutional constraints of school-enterprise cooperation}

China's market economic structure has been based on socialist public ownership with coexistence of diverse sectors of the economy to achieve sustainable development. In particular, our current school system is mostly public schools, and coexisted by other school system. For colleges, especially public colleges and universities, they have no autonomy rights and influences by long-term effects of inertia running mode, resulting in bad adapted to the current needs of social development. Therefore, the positivity for this relationship is poor. For enterprises, Chinese market economy system is still in the development stage, which indicates that the factors influenced the pros and cons of enterprise development is still very complex. Many enterprises gain greater competitive advantage by the loopholes of the system. Therefore, enterprises have weak ability to perfect current production technology and to promote product updating. According to study, the contribution rate of Chinese scientific and technological progress only $30 \%$, while $60 \%-80 \%$ in western countries. We can see that there is a large gap in these two figures. The introduction of technology application talents will bring a lot of benefits both for enterprises and high vocational colleges during development process of manufacturing enterprises. However, due to poor benefit, the conflict enterprises faced is very large. Meanwhile, there is no support from human resources and material resources in internal organization, which is another reason for involving this activity passively. This also leads a 
significant obstacles and difficulties in practical teaching. Higher vocational colleges, students and their parents think that outside-school practice has important for cultivating comprehensive quality and ability of students.

\section{Strategy for promoting sustainable development of school-enterprise cooperation}

\section{Change the traditional education mode to achieve in-depth development of school-enterprise cooperation in running schools fundamentally}

Now there are three modes of current school-enterprise cooperation in running schools. First is school-run enterprises mode that refers to college takes advantage of their industry to implement school-enterprise cooperation in running schools. Second is enterprise-run school mode that refers to enterprise establishes school independently or local government allocate public schools to schools managed by enterprise to achieve school-enterprise cooperation. Third is school-enterprise share-holding cooperation that refers to that high vocational colleges with independent legal qualification cooperate with enterprise by share-holding mode. We shall adopt new scientific and reasonable mode between high vocational colleges and enterprises to achieve sharing of project, talent and technology as well as mutual benefit and win-win result. Specifically included are as follows:

\section{School-enterprise cooperation should focus on professional development}

Core purpose of school-enterprise cooperation is to serve enterprise that involved in cooperation, which indicates the goal-oriented of the cultivation of talents. Therefore, professional construction shall be completed by enterprise and college. That is to ask each major should set up a special committee, and members of the committee shall be composed of representatives of enterprises and representatives of high vocational colleges. The primary role is to develop relevant teaching programs, to supervise implementation of plans and regular adjust and assess it. The courses, practice arrangement, practice times and time, graduation examination and graduation thesis should be mutually agreed, and then confirmed. Therefore, teaching content and teaching mode shall be made according to requirement of enterprise, considering future development trend of enterprise. Based on above, a bridge can be produced between high vocational colleges and enterprises, so the achievement of school-enterprise cooperation will be promoted better.

\section{Strengthen construction of practice base of high vocational colleges}

We shall adopt school-enterprise collaborative approach to build practice base in campus together; should be strictly simulation of real production environment to carry out practical training activities. Moreover, we shall invite some senior engineers with rich experience worked in basic job as part-time teacher so that their experience and new-type technology can be fully integrated with practical teaching. In addition, the enterprises shall set up outside-school practice base in order to allow students to deeply understand work by combination of teaching objectives, realizing the coexistence of the theory and practice of teaching mode.

\section{Establish an effective mechanism for school-enterprise cooperation in running schools}

We shall establish scientific and reasonable mechanism system in accordance with Chinese economic conditions, social development situation, future trends and basic characteristics of school-enterprise cooperation so as to achieve sustainable development of school-enterprise cooperation. The following cooperation mechanisms are usually adopted. First is incentive mechanism. School-enterprise cooperation in running schools is basically undertaken on the voluntary basis of two each other. Since it is a voluntary cooperation, it should have plenty of impetus. The role of government is critical in establishment of such a mechanism. On the one hand, education fund can promote active participating and initiative of school. On the other hand, it should be clear obligations in the formulation of relevant laws and regulations in order to promote future reform and development. Second is safeguard mechanism. It should establish effective accountability mechanisms to protect local governments, high vocational colleges and enterprises. The school-enterprise cooperation in running schools is a very strictly thing from an objective point of view. Hence, state shall formulate related laws and regulations to restrain, which could help two 
parties to clear their responsibility. That's why to establish scientific and reasonable mechanism system between local governments, enterprises and high vocational colleges to promote cooperation and to keep such activity long-term proceed.

\section{Conclusion}

In summary, combination of vocational education and corporate culture is a performance of international development of social economy. In the process of school-enterprise cooperation in running schools, high vocational colleges shall take advantage of strengthens and integrate outstanding connotation of enterprise as well as the workplace culture into education and teaching, which make a valuable contribution to cultivate more technology application talents and sustainable development of Chinese higher vocational education.

\section{Acknowledgments}

This article is a project of 12th five-year plan of Educational Science in Jinan with Vocational Education Evaluation on the Basis of Enterprise Participated as project name and 125GH282 as project number; a project of Shandong Educational Science Planning with Study on Regional Economic Structural Adjustment and Transformation of Vocational Education Development Mode as project name and 2013GZ051 as project number; a school-level educational reform project of Shandong Yingcai University with Study on Accounting Teaching Mode Innovation as project name and YCXY-X2012023 as project number; a school-level educational reform project of Shandong Yingcai University with Research Normal Form of Application-oriented Systematic Practice Teaching System as project name and YCXY-X2012005 as project number.

\section{References}

[1] Chen Qin. Difficulties and Countermeasures of School-enterprise Cooperation in High Vocational Education [D]. Southwest University, 2009 (10).

[3] Wu Jie. Return of High-level of School-enterprise Cooperation in High Vocational Education [J]. Education and Vocation, 2011 (01).

[4] Chen Hongyan, Zhao Limin. Study on Mode of School-enterprise Cooperation in Running Schools in High Vocational Education [J]. Journal of Shijiazhuang Vocational Technology Institute, 2005 (06).

[5] Hu Ailing. Study on Operating Mechanism of School-enterprise Cooperation in High Vocational Education [D]. Tianjin University, 2012 (05).

[6] Xu Jian. Study and Thinking on School-enterprise Cooperation in Running Schools in High Vocational Education [J]. Education and Vocation, 2012 (06).

[8] Liu Xun, Hu Min. Analysis of School-enterprise Cooperation in Running Schools in High Vocational Education [J]. Journal of Chongqing Industry \& Trade Polytechnic, 2010 (02).

[9] Hong Changqing. Promoting Mechanism Innovation of School-enterprise Cooperation in Running Schools in High Vocational Education [J]. Educational Review, 2014 (02).

[10] Li Huiying. Analysis of Problems of Chinese School-enterprise Cooperation in Running Schools in High Vocational Education[J]. Career Horizon, 2011 (03). 